\title{
Peran Pendidik dalam Pengembangan Identitas Diri Mahasiswa melalui Character Building
}

\author{
Is Fadhillah'1, Tri Wulan² \\ isfadhillah@gmail.com¹ ${ }^{1}$,medikaandika2@gmail.com² \\ Akademi Kebidanan Medika Wiyata Kediri 1,2
}

\begin{abstract}
Currently, educators have a big task in their role in the success of the nation's children. One of the fundamental problems currently occurring among students as the next generation is the tendency of moral degradation. This study aims to determine how far the understanding of educators is about social phenomena that occur in student identity, so it is necessary to implement a character-building program in students as an effort to develop student identity, as well as identify what efforts are made by educators in implementing character building in students of the Ganesha Husada College of Health, Kediri Regency. This research uses a qualitative case study method. In this framework, a paradigmatic analysis of social construction theory is used in analyzing the data materials of character building. Data collection was carried out through in-depth interviews. The results obtained, the social construction steps regarding character building in the campus environment of Stikes Ganesha Husada Kediri, among which the most prominent is the curriculum setting. As a capital from exemplary in each lecturer, internalization of character building which becomes a plus icon is quickly understood and practiced by students. Therefore, the implementative values of character building can eventually become a new culture for students of Stikes Ganesha Husada Kediri.
\end{abstract}

Keywords: role, educators, character building, students, moral degradation

\section{Abstrak}

Saat ini tenaga pendidik mempunyai tugas besar dalam peranannya terhadap keberhasilan anak bangsa. Salah satu permasalahan yang mendasar saat ini yang banyak terjadi di kalangan mahasiswa sebagai generasi penerus adalah kecenderungan terjadinya degradasi moral .Penelitian ini bertujuan untuk mengetahui seberapa jauh pemahaman tenaga pendidik terhadap fenomena sosial yang terjadi pada jati diri mahasiswa, sehingga perlu diterapkannya program pembentukan character building pada mahasiswa sebagai upaya pengembangan identitas diri mahasiswa, serta mengidentifikasi upaya apa saja yang dilakukan tenaga pendidik dalam mengimplementasikan character building dalam diri mahasiswa Sekolah Tinggi Kesehatan Ganesha Husada Kabupaten Kediri. Penelitian ini menggunakan metode kualitatif studi kasus, pada kerangka ini analisis paradigmatik teori konstruksi sosial yang digunakan dalam menganalisis bahan data dari character building. Pengumpulan data dilakukan melalui wawancara mendalam. Hasil penelitian diperoleh, langkah konstruksi sosial mengenai character building di lingkungan kampus Stikes Ganesha Husada Kediri diantaranya yang paling menonjol adalah setting kurikulum. Modal dari keteladanan pada diri setiap dosen, internalisasi character building yang menjadi ikon plus dengan cepat mudah difahami dan dipraktekkan mahasiswa. Oleh karena itu, nilai-nilai implementatif dari character building pada akhirnya dapat menjadi budaya baru bagi mahasiswa Stikes Ganesha Husada Kediri

Kata Kunci: peran, tenaga pendidik, character building, mahasiswa, degradasi moral 


\section{Efektor, Volume 7 Issue 2, 2020, Pages 148-163}

Is Fadhillah, Tri Wulan

\section{PENDAHULUAN}

Pembentukan karakter sangat diperlukan dalam melangsungkan kehidupan, berbangsa dan bernegara yang aman, adil dan sejahtera. Oleh karena itu, pendidikan dianggap sebagai alternatif yang bersifat preventif untuk membangun generasi bangsa yang lebih baik. Institusi formal perguruan tinggi memiliki kewajiban untuk menumbuhkan karakter yang tangguh pada setiap mahasiswanya. Hal ini disebabkan karena tidak hanya mahasiswa cerdas yang diperlukan dalam dunia pekerjaan, namun diperlukannya mahasiswa pandai dan bermoral yang menjadi benteng dari berbagai tindakan tidak terpuji, wadah untuk pengembangan diri dan menjadi seseorang yang berkepribadian unggul (Inggriyani, 2016).

Selain peranan orang tua, tenaga pendidik sebagai salah satu unsur di masyarakat dan pemerintah sangat dibutuhkan peranannya untuk mencapai tujuan pembentukan kepribadian unggul pada diri mahasiswa untuk menjadi pribadi yang beretika, bermoral dan mempunyai daya kreasi (berinovasi) tinggi. Pendidikan karakter di perguruan tinggi tidak dapat ditawar lagi dewasa ini. Penanaman moral melalui pendidikan karakter kepada peserta didik dilingkungan Perguruan Tinggi adalah kunci utama membangun karakter bangsa. Untuk itu diperlukan peran pendidik dalam menanamkan pendidikan karakter di Perguruan Tinggi. Pembentukan karakter merupakan salah satu tujuan pendidikan nasional. Pasal I UU Sisdiknas tahun 2003 menyatakan bahwa diantara tujuan pendidikan nasional adalah mengembangkan potensi peserta didik untuk memiliki kecerdasan, kepribadian dan akhlak mulia. Amanah UU Sisdiknas tahun 2003 itu bermaksud agar pendidikan tidak hanya membentuk insan Indonesia yang cerdas, namun juga berkepribadian atau berkarakter, sehingga nantinya akan lahir generasi bangsa yang tumbuh berkembang dengan karakter yang bernafas nilai-nilai luhur bangsa serta agama ( Purwanto, 2014).

Salah satu unsur penting dalam pendidikan karakter mahasiswa di perguruan tinggi adalah tenaga pendidik dalam hal ini dosen. Dosen memiliki peran penting dalam pendidikan karakter di perguruan tinggi. Dalam melaksanakan tugas utama Tri Dharma Perguruan Tinggi, yaitu melakukan pengajaran, penelitian, dan pengabdian kepada masyarakat, seorang dosen melakukan proses internalisasi nilai-nilai luhur yang kemudian menjadi budaya kampus. Dosen menjadi aktor utama dalam pembentukan dan pengembangan karakter para mahasiswa dengan keteladanan. Sebelum mendidik karakter para mahasiswa, seorang dosen paling tidak memiliki karakter yang sesuai dengan tugas utama seorang dosen. Selain itu, peran dosen yang amat penting tidak dilupakan adalah mendidik, mengajar, melatih, membimbing, dan mengevaluasi (Azhari, 2017). Harapan orang tua dan masyarakat bila berhadapan dengan tenaga pendidik adalah dapat memberikan solusi untuk menyelesaikan masalah asusila yang sering timbul di lingkungan masyarakat melalui pembentukan karakter yang lebih baik pada jati diri mahasiswa ataupun remaja sebagai generasi penerus bangsa. Hal ini dikarenakan saat ini semakin semaraknya krisis moral yang dimiliki mahasiswa.

Adanya 'pergeseran' dalam pandangan moralitas sosial pada awalnya bisa pula dipengaruhi suatu ideologi kolonial atau dampak sains-teknologi yang berpengaruh terhadap perilaku manusia. Dimana perkembangan sains-teknologi mendatangkan kesejahteraan sekaligus menimbulkan malapetaka bagi manusia (Idi, 2017). Hal tersebut didukung dengan 
adanya laporan Numbeo dalam jurnal Indonesia Corruption Watch (2015), indeks kejahatan di Indonesia adalah 46,10 kasus kejahatan yang terjadi di antaranya kriminalitas, kekerasan dan korupsi. Data terakhir dari Komisi Nasional Perlindungan Anak periode Maret 2015, kasus kekerasan seksual memiliki persentase tertinggi yaitu sebesar $35 \%$. Meningkatnya kejahatan di masyarakat bahkan berujung pembunuhan serta berkembangnya kasus bullying di sekolah maupun perguruan tinggi yang mengatas namakan suku bahkan agama, sudah menjadi sajian yang selalu hangat di surat kabar maupun televisi. Dari data KPAl juga menyebutkan angka kekerasan anak sebagai pelaku bullying (kekerasan di sekolah) mengalami peningkatan dari 67 kasus (2014) menjadi 79 kasus (2015). Sementara itu, angka anak sebagai pelaku aksi tawuran meningkat dari 46 kasus (2014) menjadi 103 kasus (2015) (Nurliyah, 2017).

Selain itu hasil survei Badan Koordinasi Keluarga Berencana Nasional (BKKBN) menyebutkan dari data penelitian pada 2005-2006 di kota-kota besar mulai Jabotabek, Medan, Jakarta, Bandung, Surabaya, dan Makassar, masih berkisar 47,54 persen remaja mengaku melakukan hubungan seks sebelum nikah. Namun, hasil survey terakhir tahun 2008 meningkat menjadi 63 persen (Hafid, 2017). Berdasarkan survei yang dilakukan Ditjen PP \& PL Kemenkes RI pada September 2014, Jawa Timur penderita HIV AIDS berjumlah 28.225 penderita. Penderita terbesar rata-rata berada di umur 20-29 tahun. Faktor utama penyebab HIV AIDS yaitu melalui hubungan seks yang tidak aman dan bergantian jarum suntik ketika menggunakan narkotika (Hidayatullah.com, 2008). Didukung dengan ungkapan Kepala Badan Narkotika Nasional Provinsi (BNNP) Jawa Timur (Jatim) yang menyatakan fakta mengejutkan mengenai jumlah pelajar pengguna narkoba. Dari data yang ada di BNNP, 20 persen pengguna narkoba kalangan pelajar. Baik SMA maupun mahasiswa dan jumlah pengguna narkoba di Jatim menempati peringkat kedua setelah Provinsi Jawa Barat. Jumlahnya kurang lebih sekitar 900 ribu orang di Jatim. Jumlah tersebut didominasi oleh usia produktif, yakni 15 hingga 35 tahun (Inggriyani, 2016). Data-data tersebut merupakan bukti nyata dari adanya penurunan degradasi moral secara umum yang terjadi pada bangsa kita saat ini, sedangkan degradasi yang banyak terjadi pada kalangan mahasiswa sebagai agen perubahan dan agen pengontrol dari suatu bangsa juga menunjukkan peningkatan yang cukup signifikan. Hal ini dikarenakan karakter mahasiswa saat ini lebih cenderung acuh tak acuh mengenai perubahan bangsa yang lebih baik ke depan. Kegiatan belajar lebih diprioritaskan untuk mendapat nilai yang baik. Hal ini perlu dipahami mengingat semakin memunculkan kekhawatiran ketika melihat realitas mahasiswa masa kini yang pemahamannya terhadap sejarah dan nilai-nilai budaya nasional menurun dratis karena runtuhnya pendidikan karakter di negeri ini.

Selain itu hal yang sangat berpengaruh besar terhadap pergeseran moralitas mahasiswa yaitu berkaitan dengan rendahnya kualitas tenaga kerja yang disebabkan oleh beberapa faktor diantaranya berupa ketidaksinkronan/kesenjangan program antara lembaga pendidikan (termasuk Perguruan Tinggi) dengan kebutuhan pasar tenaga kerja. Kesenjangan tersebut disebabkan oleh sistem pembelajaran yang diterapkan di Perguruan Tinggi saat ini masih berorientasi pada hard skill yakni menyiapkan mahasiswa yang cerdas keilmuan, cepat lulus dan segera mendapat pekerjaan. Sementara itu pembelajaran yang berorientasi pada 
kreativitas, inovatif, mandiri, jujur, disiplin, kerja keras, toleransi dan saling menghargai (pembelajaran berorientasi karakter) belum banyak diterapkan. Pendidikan berorientasi karakter saat ini sudah waktunya untuk diimplementasikan dengan serius, karena ada indikasi tentang penurunan kualitas produk pendidikan yang ditandai dengan menurunnya nilai-nilai etika, moral dan kejujuran pada sebagian besar mahasiswa. Selain itu terjadi kemunduran kepribadian sehingga tidak bisa hidup di masyarakat dikarenakan tidak bisa menyesuaikan diri dengan lingkungannya. Kejadian serupa juga dialami mahasiswa Stikes Ganesha Husada Kediri yaitu dengan menurunnya etika dalam berperilaku, terutama dalam berhadapan dengan dosen, rasa empati yang kurang pada sesama dan kurang tanggapnya mahasiswa terhadap peluang yang bersifat positif. Pola pembelajaran yang berorientasi pada karakter ini nantinya mampu menstimulasi mahasiswa sejak dini sehingga akan terbentuk watak yang mengandung nilai-nilai kemuliaan sehingga akan terwujud sumber daya insani yang berkualitas. Hal ini sesuai dengan program pemerintah yakni telah meluncurkan "pembangunan karakter untuk mendorong kesadaran dan pentingnya membangun peradaban bangsa". (Isroah,2013).

Berkaitan dengan hal tersebut menjadi tugas besar bagi seorang tenaga pendidik dalam mencapai tujuan yang diharapkan masyarakat dan bangsa saat ini, dimana harapan besar masyarakat bangsa ini ada di pundak mahasiswa. Dengan mengoptimalkan peran juga fungsi sebagai mahasiswa dalam kehidupan sosial ini dapat menjadi cara untuk merubah bangsa ini menjadi bangsa yang lebih maju dan berkeadaban. Nilai-nilai moral, akhlaq harus dijaga dengan cara mahasiswa sebagai pelopor dan publik figur bagi masyarakat, sehingga nilai-nilai agama, moral juga akhlaq dapat terus dibudayakan dan tetap menjadi identitas bangsa ini. Oleh karena itu diharapkan agar tugas pokok dan fungsi tenaga pendidik dapat memberikan peranan yang besar dalam upaya pengembangan identitas diri mahasiswa melalui pembentukan character building khususnya di Stikes Ganesha Husada Kediri dapat diterapkan sesuai dengan harapan masyarakat bangsa ini.

\section{METODE PENELITIAN}

Metode penelitian ini menggunakan metode kualitatif studi kasus yang bertujuan untuk mendiskripsikan dan memahami suatu fenomena sosial di lingkungan akademik perihal pemahaman tenaga pendidik terhadap degradasii moral pada mahasiswa yang semakin lama mengalami peningkatan serta mengidentifikasi upaya apa saja yang dilakukan tenaga pendidik dalam dalam mengimplementasikan pembentukan character building pada diri mahasiswa Sekolah Tinggi Kesehatan Ganesha Husada Kabupaten Kediri. Informan pada penelitian ini adalah stakeholder, tenaga pendidik, citivitas akademik, mahasiswa Stikes Ganesha Husada Kabupaten Kediri yang memenuhi kriteria inklusi dan ekslusi, serta bersedia menjadi informan dengan mengisi lembar informed consent.

Penelitian dilakukan di Stikes Ganesha Husada Kediri dan waktu pelaksanaan dimulai bulan Juli tahun 2020. Pengambilan data pada penelitian ini dengan melakukan wawancara mendalam pada informan yang memenuhi persyaratan dan telah mencapai saturasi data dan disimpan dalam voice recorder. Pengumpulan data sekunder melalui studi dokumentasi dengan melihat, menganalisis berbagai dokumen yang relevan meliputi data 
program implementasi pembentukan character building pada Stikes Ganesha Husada Kabupaten Kediri, serta melakukan observasi langsung ke lokasi penelitian untuk memperoleh data nonverbal dari informan selama kegiatan penelitian.. Proses analisis ini dilakukan selama proses penelitian dengan analisis kualitatif. Dalam teknik ini ada tiga komponen pokok analisis yaitu reduksi data, sajian data dan penarikan kesimpulan yang kesemuanya itu difokuskan pada tujuan penelitian (Moleong, 2014).

\section{HASIL DAN PEMBAHASAN}

Hasil

\section{Relasi Degradasi Moral dan Sosial Media.}

Perubahan sosial dan teknologi yang begitu cepat memasuki lini kehidupan sosial masyarakat cukup memberikan warna baru pada ragam wajah kehidupan. Pasalnya perubahan yang dikandungnya tidak hanya membawa progresivitas yang positif bagi perkembangan sosial masyarakat itu sendiri. Akan tetapi, pada sisi yang lain perubahan yang ditimbulkan darinya turut memberikan warna negatif bagi rekonstruksi kehidupan bersama dalam beberapa sisi dan sudut pandang.

Degradasi moral di kalangan mahasiswa akan menjadi bahan yang cukup menarik dalam semua aspeknya, dikarenakan terdapat dua sisi yang bertolak belakang dalam identitas diri mahasiswa. Hal yang mudah terbaca dalam diri mereka adalah strata sosial pendidikannya yang berbeda secara diameter dengan kalangan lain yang setara yang di bawahnya. Dengan asumsi yang sederhana, bahwa relasi ilmu pengetahuan dengan bermacam jenisnya seharusnya menjadi pengendali diri dalam melakukan dan bertindak bersama di lingkungan sosial di mana mereka berada. Tentang degradasi moral korelasinya dengan sosial media dapat dilihat pada pernyataan hasil wawancara TJ (Dosen) sebagai berikut:

"Moral remaja sudah parah, terutama di media sosial. Mereka seakan lepas kontrol dari nafas moral etik. Hal ini dapat dilihat di postingan mereka di medsos." (2020, Juli 03)

Hal senada juga diutarakan oleh AW :

"Ada penurunan atau kemerosotan moral; moral itu akhlak. Dalam konteks mahasiswa misalnya, sopan santun, unggah-ungguhnya berkurang, daya juang gak sekuat zaman dulu." (2020, Juli 08);

Menjadi jelas, bahwa kutipan dan pengamatam masyarakat tentang degradasi moral yang melanda semua kalangan khususnya mahasiswa tidak lain karena dampak sosial media yang menyelusup ke titik sendi-sendi kehidupan, sehingga pada puncaknya memengaruhi cara interaksi antarsesama baik dalam lingkungan nyata dan virtual sekaligus.

Dari pernyataan di atas tertera bahwa degradasi moral di kalangan mahasiswa dan kalangan anak muda pada umumnya telah mengalami pergeseran dan bahkan perubahan yang cukup jauh dibandingan dengan masa-masa sebelumnya, khususnya perbandingan ini bila disetarakan dengan zaman generasi-generasi tua atau sebelumnya. Pemandangan yang sangat tampak dan tidak terbantahkan dari integrasi manusia di era digital saat ini dengan 
gadget yang masuk ke dalam banyak media sosial adalah akses yang tak bisa terkendali bagi siapa saja yang menginginkannya. Tak terkecuali bagi kalangan anak muda dan di bawahnya yang sebagian besar belum bisa membedakan mana yang positif dan negatif. Sehingga kemudian, akses yang tak terkendali ini akan membawa dampak tidak baik bagi perkembangan perilaku dan tindakan seseorang sebagai bentuk negativisme dari media sosial yang digunakan selama ini, meskipun di lain sisi terdapat sisi positif dalam penggunaanya yaitu untuk mengetahui perkembangan informasi terbaru dari dunia luar, tetapi pada kenyataannya lebih banyak dampak negatif yang mereka dapatkan dari penggunaan media sosial ini, terutama dalam hal etika berperilaku dan berpakaian.

\section{Degradasi Moral dan Lingkungan Sosial.}

Melihat fakta sosial kekinian dari dampak media sosial yang netral dan butuh kepekaan tersendiri bagi seseorang sebagai pelaku utama bagaimana media ini menjadi ruang yang positif bagi diri dan lingkungan sekitar. Dengan ini maka, peran berbagai lembaga sosial baik kecil hingga yang terbesar harus hadir di tengah-tengah mereka. Lembaga keluarga adalah salah satu dari banyak lembaga sosial yang peran dan fungsinya selama ini tidak bisa dinomerduakan dalam mendidik dan memberikan sosialisasi yang tepat mengenai nilai dan norma sosial yang berlaku di tengah-tengah masyarakat. Sebagai sekolah pertama dimana seorang mengenal lingkungan yang lebih luas, lembaga keluarga tetap harus menjadi garda terdepan dalam mengawal kekokohan moral sehingga tidak tergerus oleh degradasi moral yang mulai menggerogoti sebagian struktur lembaga sosial selama ini.

Sebagai lembaga yang paling bertanggungjawab dalam membina dan mengawasi tindakan individu dan sosial, lembaga keluarga harus tersistematisasi secara massif dalam berupaya mewarnai segala bentuk tindakan moral konstruktif bagi institusionalisasi nilai-nilai bersama di lingkungan sosial dan keluarga secara khusus. Menjadi naif sekali kiranya bila peran utama keluarga yang semestinya menjadi tonggak paling kokoh dalam menghadapi degradasi moral ternyata roboh terjungkal dibanding lembaga-lembaga sosial lainnya dalam merekonstruksi moralitas di kalangan anak-anak muda. Untuk itu, maka wajar bila harapan terbesar dari semua kalangan masyarakat terutama kaum intelektual terdidik masih menaruh harapan besar bahwa lembaga keluarga harus menjadi "sekolah moral" pertama yang tidak boleh mengeluh dalam membina perkembangan moral ke arah yang lebih baik, atau dalam bahasa penelitian ini menggawangi kalangan muda masa kini dari serbuan degradasi moral yang tampak menyusupi kaula muda dalam setiap langkahnya. Mengenai peran lembaga keluarga ini AN (Kaprodi keperawatan) menyatakan:

"Bisa dari lingkungan keluarga, lingkungan masyarakat dan juga dari medsos, tapi yang paling banter itu dari medsos, sementara medsos ini ternyata juga difasilitasi oleh keluarga. Selain dari core role dari lembaga keluarga di atas, terdapat juga pantauan masyarakat pada lembaga sosial lainnya yang memiliki peran yang tidak kalah penting dengan lembaga keluarga. Sebut saja misalnya, lembaga pendidikan, lembaga agama dan lain sebagainya" (2020, Juli 16) 
Sebagai tenaga pendidik AW menganalisis;

"Yaa...mungkin dari lingkungannya, akses internet itu kan, pendidikan awal, pola asuh orang tua, lingkungan sekolah, lingkungan sekitar, lingkungan kampus. Dalam lingkungan keluarga broken home juga sangat berpengaruh dalam perhatian keluarga kepada si anak.( (2020, Juli 08)

\section{Peran tenaga pendidik dalam mengimplementasi kan pembentukan character building pada mahasiswa}

Pembentukan karakter (character building) yang digalakkan di kampus Stikes Ganesha Husada ini merupakan langkah sengaja yang dilansir untuk menjawab semua tantangan kekinian yang mulai banyak melanda kalangan muda khususnya mahasiswa di lingkungan kampus. Berkat agenda inilah kemudian muncul inisiatif respon cepat dari kalangan pengambil kebijakan untuk memberikan alternatif solusif yang bisa memberikan sumbangasih nyata dalam membangun karakter bangsa secara konkret. Bidikan pertama yang paling banyak menentukan bagi character building ini, seperti yang diungkapkan ST selaku Wadir 1:

"Peserta didik kiita sudah mengalami krisis moral, makanya di Stikes Ganesha itu membuat program yang membangun karakter mahasiswa, yang diimplementasikan secara riil tahun 2019 kemarin dan itu dimasukkan dalam kurikulum" (2020, Juli 30).

Beliau juga mengungkapkan :

"Dari sisi bidang akademik, setting kurikulum (ada materi leadership, spritual, etika kebidanan, etika keperawatan). Dari bidang kemahasiswaan, ada kegiatan mahasiswa yang mensupport mentalitas, moral mereka (tausiyah, shalat dhuha bersama). Untuk nonmuslin, persekutuan doa. Pada sisi yang lain juga kita mengadakan pelatihanpelatihan seperti ESQ" (2020, Juli 30).

Salah satu hasil wawancara tersebut membuktikan bahwa bidikan pertama dalam pembentukan character building bagi mahasiswa adalah melalui setting kurikulum. Selain setting kurikulum peran pendidik yang tidak kalah pentingnya dalam pembentukan character building adalah menjadi menjadi role model bagi mahasiswa, oleh karena itu, dalam narasi ini dosen atau pendidik dan tenaga pendidikan harus bisa menjadi role model dalam membangun karakter di lingkungan kampus. Fakta ini menjadi keniscayaan ketika para pemangku kebijakan ini mewacanakan character building dan sekaligus menjadi pelaksana garda depan dalam praksisnya. Hal ini seperti yang diungkapkan AS selaku Kaprodi Keperawatan:

"Karena kita semua itu adalah role model bagi mahasiswa, dosennya dilihat dan kita mengupayakan seperti apa yang kita sampaikan pada mereka, peran pendidik tetap menjadi panutan bagi mahasiswa, kadang dia nanti lulus lihat Bu saya ingin seperti Ibu ST, seperti Bu AN, anakanak punya pemikiran masing -masing, kita sebagai role model (2020, Juli 16) 
Hal ini menjadi penting, mengingat dua personal inti ini menjadi panutan bagi semua kalangan di mana character building ini diterapkan secara mendalam di lingkungan kampus. Konsekwensi logis yang tidak bisa dibantah dengan fakta apapun untuk pembangunan karakter adalah hadirnya preseden yang tepat sebagai referensi bagi sasaran character building di kalangan mahasiswa. Namun tidak hanya berhenti sampai di sini, langkah lebih jitu dari internalisasi character building ini juga diwujudkan dalam format tiga dimensi dengan masing-masing memiliki konsentrasi tersendiri tanpa overlapping antara satu dengan lainnya. Ketiga konsep dasar tersebut menggelinding menjadi paradigma bersama dalam membentuk karakter di kalangan mahasiswa yang menjadi target utama dalam reformasi moral yang eksis selama ini. Dalam tiga paradigma tersebut terbentuknya tiga langkah konsep yang berkaitan satu dengan lainnya dalam menjawab semua tantangan degradasi moral yang selama ini telah menghantui semua lini di kehidupan mahasiswa. Secara lebih rinci tiga langkah konsep di atas hadir dengan nama character building yang meliputi enterpreneurship, leadership dan spritualisme.

Masing-masing dari setiap konsep di atas memiliki wilayah tersendiri dalam pengembangan karakter yang lebih baik bagi kalangan mahasiswa. adapun demikian, setiap konsep di atas saling mendukung demi tercapainya paradigma bersama yang terhimpun menjadi character building:

\section{Character building; enterpreneurship}

Pada tataran pembentukan karakter di ranah enterpreneurship ini mahasiswa ditempa dengan berbagai kegiatan yang dapat menunjang efektivitas program yang berkorelasi dengan kewirausahaan. Program nyata darinya berupa pembuatan produk yang menjadi kebutuhan dasar dalam ilmu kesehatan, di antaranya infus water, makanan bergizi dan lain sebagainya. Pada kegiatan ini mahasiswa tidak hanya dituntut untuk membuat produk secara mandiri, lebih jauh dari itu mereka diharapkan bisa menawarkan produknya di tengah-tengah masyarakat. Selain dari dua tugas enterpreneurship di atas, sesi terakhir bagi mahasiswa agar benar-benar menjadi enterpreneur yang handal adalah menjual produk tersebut kepada masyarakat sebagai komsumen utama. Oleh karena itu, tantangan ini menjadi nilau plus tersendiri bagi mahasiswa dalam membentuk karakter enterpreneurship sambil lalu mereka belajar keilmuan inti selama kuliah.

\section{Character building; leadership}

Pada poin ini mahasiswa dilatih dengan ragam kegiatan formal dan nonformal dalam aktivitas keseharian di kampus, sebut saja misalnya kegiatan class meeting yang di dalamnya mencakup nilai-nilai leadership berupa pidato (public speaking). Format kegiatan ini pada intinya mengasah kemampuan mahasiswa tampil di depan umum agar nantinya mereka terbiasa menjadi pemimpin di tengah-tengah masyatakat. Pada kesempatan yang lain, kegiatan outbond yang dilakukan secara terencana oleh pihak kampus juga menambahkan di dalamnya nilai-nilai organisatoris; misalnya mahasiswa dilatih agar terbiasa memimpin dan mengorganisir teman-teman sebayanya di kampus dengan aneka kegiatan yang terstruktur dalam kagiatan outbond tersebut. Kegiatan ini pada dasarnya menanamkan rasa 
tanggungjawab di antara mereka dalam menjalankan program dan kegiatan dari kampus bersama teman-teman yang lain.

\section{Character building; spritual}

Program tiga dimensi yang mencakup ke dalam pembentukan karakter yang ketiga adalah spritualisme; kegiatan ini mencoba menyentuh sisi-sisi batiniah mahasiswa dalam hubungan vertikal ke atas beserta hubungan horizontal ke samping. Sisi ini menjadi penting diangkat ke permukaan karena dimensi spritual manusia menjadi penggerak bagi segala aktivitas di luarnya. Maka, untuk merespon semua ini kampus tidak jarang mengadakan seminar ESQ sebagai langkah awal dalam merancang program pembentukan karakter dari sisi spritual. Selain dari menghadirkan tokoh dalam seminar ESQ, sisi spritual lain yang turut disentuh dari pembentukan karakter ini adalah menjadikan malam renungan sebagai media intropeksi diri bagi diri dan lingkungan sekitar. Jalan ini dilakukan mengingat mahasiswa belum banyak yang paham tentang siapa dirinya, kemana dan akan jadi apa. Oleh karenanya, pada kagiatan yang lain kampus juga melaksanakan kajian agama yang dilaksanakan secara rutin, baik kegiatan mingguan atau bulanan yang secara intens berada di kampus Stikes. Untuk kegiatan harian misalnya selalu dikerahkan untuk shalat dhuha bersama sebagai wadah mengasah ketajaman spritual dari masing-masing mahasiswa.

Walaupun demikian, berbagai langkah yang telah dilakukan dalam upaya membangun karakter yang positif bagi kalangan mahasiswa, ternyata masih saja ada hambatan dan rintangan yang tidak mudah untuk diatasi. Tentu ragam rintangan tersebut merupakan ujian manajerial yang harus dianggap hal lumrah dalam menjalan roda organisasi yang melibatkan banyak orang. Aneka hambatan dan ragam tantangannya tidak lain dan tidak bukan ternyata juga datang dari internal sendiri. Dengan tantangan internal ini maka menjadi mungkin bahwa tantangan ini menjadi lebih berat dibanding dengan tantang dari sisi eksternal. Mengapa demikian, tentu jawabannya bisa ditebak bahwa tantang internal akan menghadapi dua sisi tepi yang berseberangan. Pada satu sisi harus menggalakkan character building sebagai misi utama pembentukan karakter, tapi pada sisi yang lain garapan agenda tersebut harus berbenturan dengan lawan dalam dari agenda itu sendiri. Benturan agenda ini pada dasarnya dapat ditelusuri dari macam-macam tantangan yang ditemukan di lapangan. Misalnya tantangan dana, kebandelan mahasiswa dan belum satunya persepsi di kalangan civitas akademika mengenai character building yang telah dicanangkan oleh semua elemen di Kampus Ganesha Husada. Asumsi dasar yang selalu mengemuka dalam menghadapi tantangan ini adalah bagaimana character building ini menjadi paradigma bersama di lingkungan kampus, baik dari pimpinan tertinggi hingga kalangan bawah sekaligus, seperti yang diungkapkan AN dalam wawancara:

"Mungkin kita perlu persamaan persespi di civitas akademika terlebih dulu, kalau sudah persepsi sama, maka pasti tidak akan ada mis dengan teman yang lain". (2020, Juli 16) 


\section{Efektor, Volume 7 Issue 2, 2020, Pages 148-163}

Is Fadhillah, Tri Wulan

Pada sisi yang lain seorang Dosen bernama EL juga mengungkapkan,

"Bahwa harus ada peraturan yang dibarengi dengan punishment bagi mereka yang melanggar. Demikian pula ada reward bagi mereka yang baik (ucapan terima kasih, mahasiswa teladan, piagam dll)". (2020, Juli 22) .

Setelah bertemunya agenda dan berjalan sesuai dengan harapan seperti yang diprogramkan, maka harapan terbesar bagi character building di lingkungan kampus adalah hadirnya budaya baru sebagai antitesis dari periode sebelumnya yang dianggap keluar dan menyimpang dari pembangunan karakter yang ada saat ini. Konstruksii sosial paling nyata sebagai hasil dari produk pembentukan karakter ini adalah bangkitnya budaya baru di kalangan mahasiswa yang berbentuk: 1) Greget yang lebih baik dari pada sebelumnya dalam menangkap peluang terkait hal yang positif; 2) Cepat tanggap dan ramah dengan lingkungan bersama; 3) Sopan santun dengan sesama semakin baik terutama etika komunikasi dengan dosen; 4) Kebiasaan menyapa terlebih dahulu. 5) Mempunyai jiwa empati yang lebih tinggi.

Hasil dari budaya baru yang lebih baik ini diharapkan menjadi karakter alumni yang terus melekat hingga akhir hayat dalam mengabdi bersama masyarakat. Sederhananya, karakter yang telah diperoleh dari program character building ini harus menjadi ciri khas dari semua kalangan terutama bagi mahasiswa yang akan terjun setelah mereka lulus dari kampus tercinta. Dengan demikian, selama ini karakter itu telah melembaga dengan baik dari kalangan mahasiswa sebagai target awal character building ini. Dari semua penyajian data ini menjadi tampak bahwa character building yang digalakkan oleh kampus Stikess Ganesha Husada Kediri untuk merespon perkembangan moralitas anak muda yang kemudian dikenal dengan degradasi moral menjadi kegiatan intens yang berkesinambungan yang bermula sejak mereka masuk pertama kali ke kampus hingga mereka lulus dan menjadi alumni dan ini menjadi karakter mereka bersama lingkungan sosial masyarakat di mana mereka mengabdi sebagai tenaga kesehatan kelak.

Pada poin ini, nilai plus dari Kampus Stikes Ganesha Husada Kediri sebagai kampus teladan dalam character building di kalangan mahasiswa dan menjadi referensi masa depan dalam menghadapi zaman yang penuh dengan tantangan etika dan moral. Maka, tidak salah kiranya bila segala tantangan dan rintangan zaman yang kini mulai mencuat ke permukaan ini mendapat respon cepat dari berbagai pihak/civitas akademika untuk bersama-sama membangun kualitas moral bangsa sesuai dengan peran dan fungsi seseorang di lingkungan sosial masyarakat. Preparasi character building ini tidak lain dan tidak bukan adalah merupakan langkah rekonstruktif dalam membingkai moralitas mahasiswa dalam lingkungan sosial yang demikian global sebagai bentuk dari kesiapan anak muda masa kini menyongsong masa depan yang lebih cerah dan menjanjikan. Oleh karena itu, persiapan masa kini untuk masa depan dalam lingkup character building di lembaga pendidikan merupakan suatu kewajiban/tanggungjawab moral yang tidak lagi bisa ditawar oleh siapapun dan lembaga apapun. 


\section{Pembahasan}

Dari penyajian data yang ada peneliti kemudian memberikan perspektif teori sebagai kacamata pembacaan terhadap data yang telah peneliti dapatkan. Adapun perspektif teori yang digunakan pada pembahasan ini adalah teori konstruksi sosial Peter L. Berger dan Thomas Luckmann. Teori ini secara jelas memberikan aksioma bahwa dalam lingkungan sosial masyarakat baik dalam lingkup mikro atau makro tidak akan bisa lepas dari tiga konsep dasar teori konstruksi sosial, yaitu; eksternalisasi, internalisasi dan objektivasi (Berger, 1994). Dimana dalam kerangka ini analisis paradigmatik teori konstruksi sosial dalam menganalisis bahan data dari character building memberikan sudut pandang yang cukup cerah dan prospektif yang berarti, bahwa character building sebagai data temuan penelitian menunjukkan eksistensi pembentukan karakter tidak bisa keluar dari respon sosial di mana karakter tersebut menjadi kerangka bersama. Maksud dan tujuannya ialah bagaimana pembangunan karakter dari lingkungan tertentu menjadi jawaban simeteris bagi lingkungan sosial masyarakat yang mengalami krisis moral yang kemudian dikenal sebagai degrasi moral.

Menurut Tanis (2013) dari hasil penelitiannya menyebutkan, pendidikan karakter menjadi sumber nilai dan pedoman bagi mahasiswa untuk mengembangkan kepribadian menjadi pribadi yang smart and good. Selain itu dapat membantu mahasiswa selaku warga Perguruan Tinggi agar mampu mewujudkan nilai-nilai dasar dalam menerapkan ilmunya secara bertanggung jawab terhadap kemanusiaan yang bertanggung jawab, memiliki kemampuan berpikir, bertindak, memiliki pola pikir dan pola sikap yang baik dan berpandangan luas sebagai intelektual.Pendidikan Character Building merupakan salah satu cara menggali, memahami, atau mencari potensi yang ada pada diri dan mengintegrasikanya kepada sesama. Ini juga sangat penting karena sebagian besar mahasiswa lebih mengutamakan untuk mendapatkan nilai yang bagus, membuat dirinya pintar tanpa memahami potensi yang ada dalam dirinya. Pendidikan Character building sangat bermanfaat dan mendukung siswa mengenal diri sendiri, memahami kelebihan dan kekurangan, dan yang lebih penting lagi adalah membangun hubungan dengan sesama. Sebab itu, melalui pendidikan karakter dapat terbentuk kepribadian seseorang yang merupakan hasil perpaduan dari berbagai faktor yang saling terikat satu dengan yang lainnya.

Pada sisi ini, character building tidak lain adalah bentuk eksternalisasi yang dilakukan secara intens oleh suatu lembaga yang secara masif melibatkan semua civitas akademika di lingkungan Stikes Ganesha Husada Kediri sebagai pelaku utama bagi pembentukan karakter di kalangan mahasiswa. Kegiatan ini bukan langkah "langit" yang tanpa respon kepada realitas sosial di mana kegiatan ini dibumikan. Akan tetapi, dapat dijelaskan bahwa character building ini sebagai langkah serius dalam upaya membangun karakter di kalangan mahasiswa terkait dengan prospek mereka sebagai agen perubahan di lingkungan sosial kemasyarakatan. Karena bagaimanapun, character building yang digagas oleh lembaga dengan para stakeholder di dalamnya sebagai pelaku dalam upaya menanamkan nilai-nilai baru sebagai antitesis dari degradasi moral yang merajalela selama ini tidak lain semata sebagai konstruksi sosial yang secara kuat dibangun dalam upaya membentuk 
sosialisasi lingkungan kampus yang sesuai dengan keinginan bersama serta nilai-nilai yang dipegangi sebagai konstruksi positif bagi kampus dan menjadi ciri khas profesionalisme dalam dunia kerja di mana mereka akan menjadi bagian di dalamnya. Sederhananya, eksternalisasi character building ini berupaya membangun budaya baru yang selama ini belum mereka ketahui dan lakukan secara bersama. Oleh karena itu, untuk menjelaskan semua langkah konstruksi sosial mengenai character building di lingkungan kampus Stikes Ganesha Husada dapat ditemukan pada narasi-narasi selanjutnya.

Peran civitas akademika dalam partisipasinya bagi character building di kalangan mahasiswa berbentuk ragam program di antara yang paling menonjol adalah setting kurikulum. Setting kurikulum ini bertujuan untuk merespon tantangan kekinian yang mulai merasuki kalangan mahasiswa yang berwajah degradasi moral. Walaupun pada sisi yang lebih dalam keberadaan kurikulum ini sebagai pembentukan karakter yang berbasis pada pandangan masa depan dengan jangkauan yang cukup jauh. Tentunya kurikulum ini sebagai bahan konstruksi sosial yang berbasis pada kerangka berpikir, perilaku, emosional dan spritual dalam membentengi segala tantangan zaman. Pengaturan kurikulum khusus ini kemudian bermuara pada terwujudnya mata kuliah-mata kuliah spesifik yang secara tersurat membahas dan menekankan pada character building dari agenda besar kampus tersebut. Guna dan agar agenda besar kampus tersebut benar-benar dapat terukur sebagai kampus yang mengayakan diri dengan character building, maka menjadi keniscayaan bila manifestasi darinya termaktub dalam pelaksanaan mata kuliah khusus yang berkaitan dengan character building. Di antara beberapa mata kuliah tersebut berupa mata kuliah spritual nursing, pendidikan Pancasila, pendidikan agama, etika profesi, dan pendidikan antikorupsi.

Di sisi lain peran dosen sebagai pemangku kebijakan dalam membuat kurikulum serta menjalankannya dalam bentuk mata kuliah, maka langkah nyata dari implementasi character building tersebut dosen dapat dilihat sebagai role model terdepan dalam pembangunan karakter di tengah-tengah lingkungan kampus. Anggapan dasarnya sangat mudah, yakni dosen menjadi preseden atau contoh panutan bagi semua elemen mahasiswa di kampus atau di luar dalam beretika, berperilaku dan bertindak. Semua itu menjadi acuan bagi mahasiswa pun dalam bertindak, berperilaku dan beretika di dalam dan di luar kampus. Dengan bermodal keteladan ini, character building di kalangan mahasiswa diharap mudah diserap dan tersosialisasikan (Berger, 1994) secara masif dan terukur sehingga kemudian menjadi fakta objektif yang tidak lagi diragukan keberadaannya. Objektivasi ini dalam konsruksi sosial menjadi puncak dari usaha sosial dalam membangun masyarakat yang dalam hal ini terbingkai dalam kerangka character building di lingkungan kampus Ganesha. Dengan bermodalkan keteladanan pada diri setiap dosen, internalisasi character building yang menjadi ikon plus dari kampus Stikes Ganesha dengan cepat dan mudah merasuk ke dalam diri mahasiswa yang menjadi target bidikan nilai-nilai pembangunan karakter. Dalam pada itu, character building adalah sebagai ujung pangkal bagi pengembangan identitas diri pada mahasiswa dalam upaya menghadapi tantangan masa depan. Untuk itu, pantas dan patut kiranya bila derivasi dari aktualisasi pembangunan karakter itu tertuang dalam triadik segi tiga praktis yang masing-masing memiliki keterkaitan yang padu tak dipisahkan. 
Kegiatan spritulisme adalah salah satu contohnya yang menjadi bagian dari pembentukan karakter, pada kegiatan ini mahasiswa dilatih untuk selalu dekat kepada Tuhan Yang Maha Esa dalam setiap kiprah dan tingkah lakunya. Paling tidak dalam praktik ini ketajaman emosionalnya (ESQ) menjadi salah satu garapan dari pembentukan karakter di Stikes Ganesha Husada. Adapun demikian, menyesuaikan dengan tren masa kini mereka juga dilatih membuat Tiktok dengan kontens yang membawa pesan-pesan moral sebagai counter ideologis dari kecenderungan anak muda masa kini menampilkan tiktok yang tidak bernilai pendidikan sama sekali. Di samping itu, malam renungan juga menjadi bagian penting dari rentetan acara pembentukan karakter di kalangan mahasiswa yang dalam hal ini bisa berbentuk kegiatan yang menggugah kesadaran diri, keluarga dan lingkungan sekitar sehingga menjadi introspeksi diri mahasiwa, sehingga akan muncul rasa syukur, toleransi dan lain-lain. Pada kegiatan ini juga dilaksanakan sentuhan rohani oleh pameteri yang memang ahli di bidangnya. Tujuannya tidak lain agar kepekaan, ketakwaan, keimanan menjadi landasan utama dalam berperilaku, bertindak dan beretika di lingkungan sosial masyarakat.

Pada sisi lain, leadership atau kepemimpinan juga tidak kalah menariknya bagi pembentukan karakter di kalangan mahasiswa. Mereka diberi tanggungjawab mengorganisir teman-teman sekelompoknya dalam membuat suatu kegiatan bersama di antara mereka, sehingga muncul kerjasama yang baik antar tim yang nantinya dapat mereka gunakan sebagai modal di dunia kerja. Dalam kegiatan kepemimpinan ini mereka dilatih sekaligus mempraktikkan diri dalam public speaking atau berpidato di depan teman-temannya untuk melatih dan menumbuhkan rasa percaya diri mahasiswa dengan tetap mengacu kepada logika kepemimpinan yang berlandaskan pembentukan karakter, sehingga akan terbentuk cara komunikasi yang baik terhadap sesama. Pada dasarnya bentuk kegiatan demikian bertujuan untuk menggali potensi terpendam dalam diri setiap mahasiswa agar menjadi bakat yang terekspos ke permukaan dengan segala bentuknya dari masing-masing mahasiswa.

Kegiatan inti yang lain juga menjadi bagian dari pembentukan karakter adalah enterpreneurship di kalangan mahasiswa yang diinisiasi oleh para pemangku di kampus tercinta ini. Dalam kegiatan enterpreneurship ini mahasiswa distimulus jiwa kewirausahannya dalam membuat produk, menawarkan produk serta strategi penjualannya. Kegiatan ini pada dasarnya memerlukan talenta tersendiri yang perlu dirangsang agar bisa dirasakan kehadirannya di tengah-tengah masyarakat. Eksplorasi bakat yang terpendam ini memerlukan stimulus dari luar sebagai penarik dari potensi yang dimiliki mahasiswa. Pada kegiatan enterpreneurship ini mahasiswa dilatih untuk berhadapan langsung dengan psikologi sosial di mana produk itu ditawarkan, dan dijual sekaligus. Pertemuan diri dengan masyarakat luas yang dilakukan mahasiswa paling tidak sebagai bentuk nyata dari realitas sebenarnya tentang bagaimana masyarakat merespon produk dan penjualan yang dibuat oleh mahasiswa serta sistem ekonomi masyarakat yang sesungguhnya. Oleh karena itu, mahasiswa diharap bisa membaca secara teoritik pada kondisi sosial kemasyarakatan yang dihadapi mahasiswa itu sendiri, selain itu juga akan terbentuk mahasiswa yang aktif, kreatif, tanggap dalam melihat peluang yang positif dalam kegiatan enterpreuner serta pantang menyerah.. Itulah 
sebenarnya nilai karakter yang diharapkan dari jiwa enterpreneurship yang digalakkan oleh kampus.

Maka dari itu, nilai-nilai implementatif dari character building pada akhirnya diharapkan menjadi budaya, tradisi, pemahaman, konstruksi sosial, perilaku dan tindakan baru di kalangan mahasiswa yang merupakan hasil dari kristalisasi program pembentukan karakter yang dicanangkan sebelumnya. Dengan bahasa lain, keberadaan budaya baru di kalangan mahasiswa sebagai produk dari eksternalisasi, internalisasi dan objektivasi pembentukan karakter telah menuai hasil yang mencengangkan dalam bentuk aksi simetris antara misi program kegiatan dengan fakta dan harapan di lapangan Dengan adanya fakta dan harapan baru di kalangan mahasiswa maka konstruksi sosial oleh pemangku kebijakan benar-benar menjadi realitas sosial yang akan terus berlanjut hingga dalam batas waktu yang tidak ditentukan. Dalam arti, pembentukan karakter di kalangan mahasiswa akan terus dilakukan sampai menjadi fakta sosial yang tidak lagi dipertanyakan keberadaannya, malah harapan terbesarnya kontruksi sosial berupa fakta tersebut menjadi bagian dari mereka dalam bertindak, berpikir, berperilaku dalam kehidupan bersama di lingkungan sosial kesehariannya. Bila ini yang terjadi, maka tidak menutup kemungkinan dialektika sosial interaktif antara degradasi moral dengan character building akan dimenangkan oleh posisi yang disebut terakhir. Maka untuk menjelaskan semua konstruksi sosial character building yang disuguhkan oleh Kampus Stikes Ganesha Husada dapat digambarkan pada konseptualisasi bagan berikut:

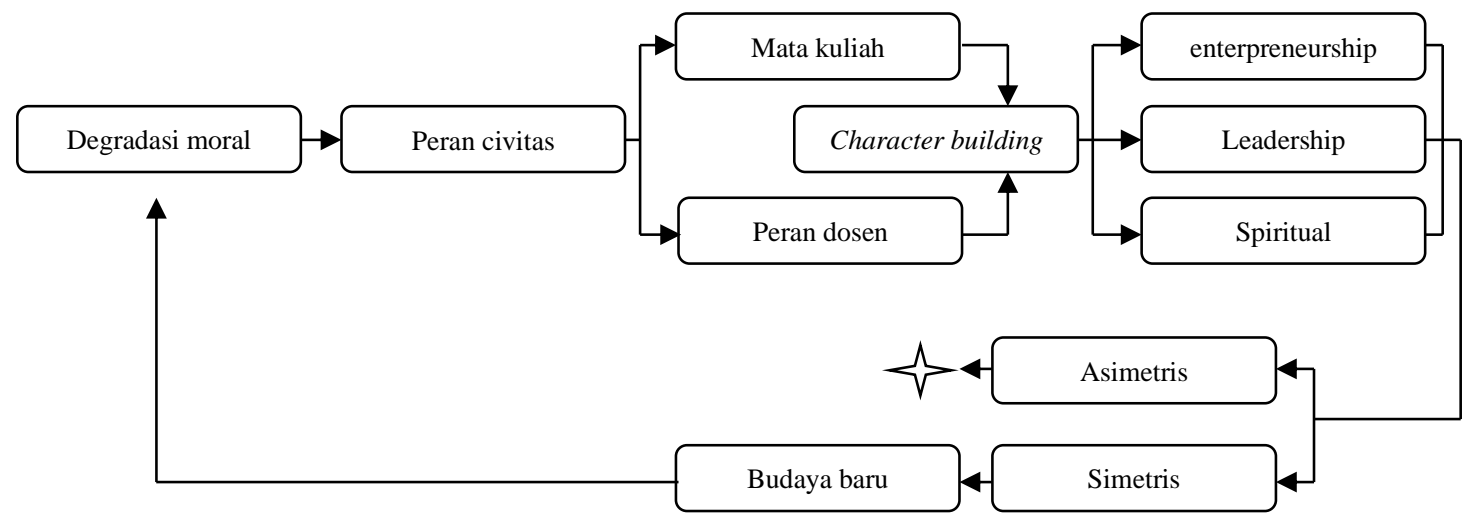

Gambar 1. Bagan Tenaga Pendidik Dalam Penerapan Character Building (Enterpreunership, Leadership, Spiritual) Mahasiswa di Stikes Ganesha Husada Kediri

Bagan ini secara panjang lebar telah dijelaskan pada bagian pembahasan ini dengan aneka konsep dan eksplanasi yang terjadi di lingkungan Kampus Stikes Ganesaha Husada. Tetapi sebagai penegas pada penjelasan kali ini dapat diutarakan bahwa langkahlangkah yang dilakukan kampus secara nyata terekam dalam gambar bagan skematik di atas. Sebagai bentuk akhir dari pembentukan karakter di kampus tersebut dapat diuraikan dari arah panah pada bagan skematik di atas dengan terus berkesinambungan tak kenal henti pada satu titik saja, tentu dengan maksud dan tujuan bahwa program character building di lingkungan kampus dilaksanakan secara terus-menerus semenjak mahasiswa diterima menjadi bagian dari kampus tersebut -awal menjadi mahasiswa baru- hingga mereka lulus kelak dari Stikes Ganesha Husada. Demikian pula, pada kolom terakhir "budaya baru" 
sebagai hasil dari pembentukan karakter di kalangan mahasiswa dimaksudkan untuk menjadi bekal bagi mereka di mana suatu saat nanti akan menjadi alumni yang berkerakter seperti yang diinginkan almamaternya. Bahkan jangkauan lebih jauh, mereka bisa menjadi penyaring sosial yang selama ini menggerogoti etika sosial bersama yang disebut degradasi moral. Maka pada gambar bagan di atas titik panah paling belakang mengarah kepada kolom degradasi moral. Itulah sebenarnya dialetika tak berkesudahan dari tolak konsep awal hingga hasil akhir yang diimpikan dengan proses tiada henti (Berger \& Luckmann, 2013).

\section{SIMPULAN}

Hasil pembahasan dapat disimpulkan character building tidak lain adalah bentuk eksternalisasi yang dilakukan secara intens oleh suatu lembaga yang secara masif melibatkan semua civitas akademika di lingkungan Stikes Ganesha Husada Kediri sebagai pelaku utama bagi pembentukan karakter di kalangan mahasiswa dalam mengatasi degradasi moral. Peran civitas akademika dalam partisipasinya bagi character building di kalangan mahasiswa berbentuk ragam program mulai dari seting kurikulum dan role mode dari peran pendidik yang diaktualisasi dalam triadik segi tiga praktis diantaranya melalui kegiatan spiritualisme, leadership dan enterpreunership yang dapat digunakan sebagai sumber nilai dan pedoman bagi mahasiswa untuk mengembangkan identitas diri menjadi lebih baik, serta diharapkan dengan adanya implementasi character building di institusi/ perguruan tinggi dapat mendukung mahasiswa dalam mengenal diri sendiri, memahami potensi yang dimiliki serta dapat mengintegrasikannya dan yang lebih penting adalah membangun hubungan sesama, serta menjadi budaya baru mahasiswa dalam berperilaku, terutama di Stikes Ganesha Husada Kediri

\section{DAFTAR RUJUKAN}

Azhari, Devi Syukri dan Alaren. 2017. Peran Dosen Dalam Mengembangkan Karakter Mahasiswa Jurnal Pelangi (Online) Vol. 9 No.2 .Halaman 88-97. https://doi.org/10.22202/jp.2017.v9i2.1856 diakses 3 Agustus 2019.

Berger, Peter L. 1994. Langit Suci; Agama Sebagai Realitas Sosial. Jakarta: LP3ES

Berger, Peter $L$ dan Thomas Luckman. 2013. The Social Construction of Reality; a Treatise in Sociology of Knowledge. Terj : Hasan Basari. Jakarta: LP3 ES.

Hafid, ahmad Uncategorized. October 14, 2017. Fenomena Seks Bebas Di Kota https://hmjakuntansiuinmalang.wordpress.com/fenomena-seks-bebas-di-kotapendidikan/. Diakses 12 Agustus 2019 on-line.

Hidayatullah.com. Desember 21, 2008 BKKBN: 63 Persen Remaja Berhubungan Seks di Luar Nikah. https://beritamaya.wordpress.com/2008/12/21/bkkbn-63-persen-remajaberhubungan-seks-di-luar-nikah/ Diakses 12 Agustus 2019 on-line.

Idi, Abdillah, Jamali Sahrodi. 2017. Moralitas Sosial dan Peranan Pendidikan Agama. Jurnal Intizar, (online) Volume 23, Nomor 1, Halaman 8 https://doi.org/10.19109/intizar.v23i1., diakses 8 Agustus 2019.

Isroah. 2013.Implementasi Pendidikan Karakter Dalam Perkuliahan Perpajakan Pada Mahasiswa Jurusan Pendidikan Akuntansi Fise Universitas Negeri Yogyakarta. 
Jurnal Pendidikan Akuntansi Indonesia, (online) Vol. XI, No. 1

https://journal.uny.ac.id/index.php/jpakun/article/view/1682 diakses 8 Agustus 2019.

Inggriyani, Feby. 30 April 2016. Pentingnya Pendidikan Karakter Pada Mahasiswa. Prosiding Seminar Nasional Menjadi Guru Inspirator "Kenali dan Kembangkan Kemampuan Intelegensi Emas untuk Indonesia Emas" PGSD FKIP Universitas Muhammadiyah Purwokerto.

Moleong. J. Lexy.2014. Metode Penelitian Kualitatif. Bandung: PT. Remaja Rosdakarya

Nurliyah, Hasan Bisri dll. 2017. Penerapan Nilai-Nilai Karakter Melalui Program Intrakurikuler Dan Ekstrakurikuler Aplication Of Character Values Through Intracurricular And Extracurricular Programs.Jurnal Didaktika Tauhidi (Online) .Volume 4 Nomor Halaman 60. http://dx.doi.org/10.30997/dt.v4i1.824 diakses 9 Agustus 2019.

Purwanto.D (2014). Pendidikan Karakter. Yogyakarta: Familia. Pengembangan Perangkat Pembelajaran. Yogyakarta: Gaya Media.

Tanis, Hibur. 2013. Pentingnya Pendidikan Character Building Dalam Membentuk Kepribadian $\begin{array}{llll}\text { Mahasiswa } & \text { Jurnal } & \text { Humaniora } & \text { Vol.4 }\end{array}$ https://journal.binus.ac.id/index.php/Humaniora/article/view/3564 diakses 9 Agustus 2019. 